\title{
Complex chronic conditions in children and adolescents: hospitalizations in Brazil, 2013
}

\author{
Condições crônicas complexas em crianças e adolescents: \\ internações no Brasil, 2013
}

Erly Catarina de Moura ${ }^{1}$

Martha Cristina Nunes Moreira ${ }^{2}$

Lívia Almeida Menezes ${ }^{2}$

Isadora Almeida Ferreira ${ }^{2}$

Romeu Gomes ${ }^{2}$

${ }^{1}$ Faculdade de Saúde Pública, Universidade de São Paulo. Av. Dr. Arnaldo 925, Sumaré. 01255-001 São Paulo SP Brasil. erlycm@gmail.com

${ }^{2}$ Instituto Fernandes Figueira, Fiocruz. Rio de Janeiro RJ Brasil.

\begin{abstract}
This article aims to estimate the extent of hospitalizations for complex chronic conditions in Brazil. Data from the Hospital Information System for 2013 were compiled according to the International Classification of Diseases $10^{\text {th }}$ Revision. Hospitalization rates were estimated according to region, sex, age and disease chapter, taking into account the 2012 population as a reference, as well the percentage of highly complex procedures and mortality rates. Public hospitals treated 190,000 inpatients in 2013. The rate was highest among the population in the South of Brazil, those who were male and children under the age of one. The rate was lowest among the population in the North, females and children aged between 10 and 14years. The mean duration of hospitalization was six days, the percentage of highly complex procedures was $13.5 \%$ and the mortality rate was $1.3 \%$. The three most common causes for hospitalizations were diseases of the respiratory system, neoplasms and diseases of the nervous system. The incidence of complex chronic conditions is 331 inwards per 100,000 children and adolescents in Brazil, with an estimate of 240,000 children and adolescents hospitalized. This panorama points to the problem as an emergent public health issue in Brazil.
\end{abstract}

Key words Chronic disease, Children, Adolescents, Hospitalization, Brazil
Resumo O objetivo deste artigo é estimar a magnitude das internações por doenças crônicas complexas no Brasil. Dados do Sistema de Informações Hospitalares referentes a 2013 foram compilados de acordo com a Classificação Internacional de Doenças $10^{a}$ revisão. Taxas de internação foram estimadas de acordo com a região, sexo, idade e doença, tendo como referência a população de 2012, bem como o percentual de procedimentos de alta complexidade e as taxas de mortalidade. Hospitais públicos tiveram 190.000 pacientes internados em 2013. A taxa foi maior entre a população do Sul do Brasil, entre homens e crianças menores de um ano de idade. A taxa foi menor entre a população do Norte, entre mulheres e crianças de 10 a 14 anos de idade. A duração média de internação foi de seis dias, a porcentagem de procedimentos de alta complexidade foi de $13,5 \%$ e a taxa de mortalidade foi de 1,3\%. As três causas mais comuns para internações foram as doenças do sistema respiratório, neoplasias e doenças do sistema nervoso. A incidência de hospitalização por doenças crônicas complexas foi 331 para 100.000 crianças e adolescentes no Brasil, com uma estimativa de 240.000 crianças e adolescentes hospitalizados. Esse panorama aponta para as doenças crônicas complexas como problema emergente em saúde pública no Brasil.

Palavras-chave Doença crônica, Crianças, Adolescentes, Hospitalização, Brasil 


\section{Introduction}

Chronic conditions include a wide range of health problems: non-transmissible conditions, persistent transmissible conditions, irreversible mental disorders and physical/structural deficiencies, all of which limit functionality, as well as infectious diseases including the human immunodeficiency virus (HIV) and tuberculosis that demand continuous and long-term treatment ${ }^{1}$.

This generic definition does not make it any less important to better understand cases of complex chronic conditions (CCC) according to the life cycle. CCC in childhood and adolescence includes multi systemic, congenital and acquired diseases. The main characteristics of CCC are functional limitations, specialized care needs and technological dependence ${ }^{2}$. CCC is irreversible and represents a high social cost for patients and their families, demanding household and community adaptations, as well as an agile health system with high complexity and multiple professional assistance ${ }^{3-7}$.

The prevalence of CCC among children and teenagers is growing around the world because of the reduction in infant mortality, improvements in surgical techniques and biomedical engineering, increased immunization cover and healthcare and improvements in social indicators. In the United States of America, CCC accounted for almost $16 \%$ of the hospitalized population under the age of 18 years in the year $2000^{8}$, and saw the hospitalization rate of children under four double from $1991 / 93$ to $2003 / 05^{9}$. The number of children aged less than 18 years hospitalized for CCC in the USA also increased between 1997 and $2006^{10}$. In 2009 in Santiago, Chile, CCC accounted for approximately $60 \%$ of hospitalizations for children under the age of 15 years $^{11}$. In Canada ${ }^{12}$, data from three national studies between 2001 and 2004 showed CCC prevalence to be between $13 \%$ and $18 \%$ among children and adolescents (under 18years).

In Brazil, prevalence data about CCC are not yet available, but an increase of cases is also expected, resulting in an increased demand for care and hospitalization. Then, it is not possible to retract any epidemiological status. This article is the first in this subject and aims to estimate the magnitude of CCC hospitalizations in Brazil, thereby seeking to support health planning in this subject and providing epidemiological data.

\section{Methods}

In Brazil, all public and some private hospitals contracted by the Brazilian Health System provide electronic data on patients immediately after being discharged through the Ministry of Health's National Hospital Information System. In this way, health institutions are reimbursed for part of the costs of hospitalizations. For this analyses, data about CCC hospitalizations for all children and adolescents aged less than 18 years old, in those hospitals, were compiled from data composed by the Minister of Health collected directly from the primary source - the admission guide, which is provided by each hospitalization. All the hospitalizations from 2013 were retrospectively analyzed, characterizing it as a survey study.

For this study, a disease list of CCC was compiled, based on the International Classification of Diseases (10 $0^{\text {th }}$ Revision; ICD-10 $)^{13}$, Feudtner et al. ${ }^{14}$ and clinical opinion (Chart 1 ).

Data from 2013 relating to the list were drawn from the Information System and the number of inpatients was disaggregated by region, sex, age and ICD-10 chapter $^{13}$. The year 2013 was chosen because this was the most recent year for which all national data had been consolidated.

Data were tabulated and analyzed with the assistance of the Statistical Package for the Social Sciences. Proportions of hospitalizations were calculated for each category, considering a confidence interval of $95 \%$. Hospitalization rates were also estimated taking into account the 2012 population as a reference.

Additionally, besides to estimate the magnitude of CCC hospitalizations, the duration of the hospitalization, the percentage of highly complex assistance and mortality rates were calculated enabling the three most common groups to be identified and analyzed according to ICD identification.

\section{Results}

In 2013, public hospitals received 190,000 inpatients (Table 1), meaning a rate of 331 hospitalizations per 100,000 inhabitants aged less than 18 years old. The South Region had the highest rate and the North the lowest. The rate is higher among male inpatients, and the rate for children under the age of one year was above 1,000 per 100.000 inhabitants. 
Chart 1. Diagnoses of chronic clinical conditions, according to International Classification of Diseases $\left(10^{\text {th }}\right.$ Revision; ICD-10) chapter, subcategory and code.

\begin{tabular}{|c|c|c|}
\hline Chapter & Subcategory & Code \\
\hline $\begin{array}{l}\text { Certain infectious and parasitic } \\
\text { diseases }\end{array}$ & Human immunodeficiency virus (HIV) disease & B20-B24 \\
\hline Neoplasms & Neoplasms & C00-D48 \\
\hline \multirow{8}{*}{$\begin{array}{l}\text { Diseases of the blood and } \\
\text { blood-forming organs and } \\
\text { certain disorders involving the } \\
\text { immune mechanism }\end{array}$} & Anaemia due to enzyme disorders & D55 \\
\hline & Thalassaemia & D56 \\
\hline & Sickle-cell disorders & D57 \\
\hline & Other hereditary haemolytic anaemias & D58 \\
\hline & Acquired haemolytic anaemia & D59 \\
\hline & Combined immunodeficiencies & D81 \\
\hline & Immunodeficiency associated with other major defects & D82 \\
\hline & Common variable immunodeficiency & D83 \\
\hline \multirow{5}{*}{$\begin{array}{l}\text { Endocrine, nutritional and } \\
\text { metabolic diseases }\end{array}$} & Metabolic disorders of amino-acids & E70-E72 \\
\hline & Metabolic disorders of carbohydrates & E73-E74 \\
\hline & Metabolic disorders of lipids & E75 \\
\hline & Combinations of metabolic disorders & E76-E78 \\
\hline & Cystic fibrosis & E84 \\
\hline \multirow{3}{*}{$\begin{array}{l}\text { Mental and behavioral } \\
\text { disorders }\end{array}$} & Mental retardation & F70-F79 \\
\hline & Disorders of psychological development & F80-F89 \\
\hline & Hyperkinetic disorders & F90 \\
\hline \multirow[t]{5}{*}{ Diseases of the nervous system } & Multiple sclerosis & G35 \\
\hline & Other acute disseminated demyelination & G36 \\
\hline & Other demyelinating diseases of central nervous system & G37 \\
\hline & Epilepsy & G40 \\
\hline & Cerebral palsy and other paralytic syndromes & G80-G83 \\
\hline \multirow{2}{*}{$\begin{array}{l}\text { Diseases of the circulatory } \\
\text { system }\end{array}$} & Cardiomyopathy & I42-I43 \\
\hline & Other conduction disorders. & I45-I49 \\
\hline \multirow[t]{3}{*}{$\begin{array}{l}\text { Diseases of the respiratory } \\
\text { system }\end{array}$} & $\begin{array}{l}\text { Bronchitis; Emphysema; Other chronic obstructive } \\
\text { pulmonary disease }\end{array}$ & J40- J44 \\
\hline & Asthma; Status asthmaticus & $\mathrm{J} 45-\mathrm{J} 46$ \\
\hline & Bronchiectasis & $\mathrm{J} 47$ \\
\hline \multirow[t]{4}{*}{ Diseases of the digestive system } & Crohn's disease, & K50 \\
\hline & Ulcerative colitis & K51 \\
\hline & Other noninfective gastroenteritis and colitis & K52 \\
\hline & Diseases of liver (except alcoholic) & K71-K77 \\
\hline $\begin{array}{l}\text { Diseases of the genitourinary } \\
\text { system }\end{array}$ & Renal failure & N17-N19 \\
\hline \multirow{8}{*}{$\begin{array}{l}\text { Congenital malformations, } \\
\text { deformations and } \\
\text { chromosomal abnormalities }\end{array}$} & Nervous system & Q00-Q07 \\
\hline & Circulatory system & Q20-Q28 \\
\hline & Respiratory system & Q30-Q34 \\
\hline & Congenital malformations of digestive system & $\begin{array}{l}\text { Q39- Q40; } \\
\text { Q42-Q43 }\end{array}$ \\
\hline & Congenital absence, atresia and stenosis of small intestine & Q41 \\
\hline & Urinary system & Q60-Q64 \\
\hline & $\begin{array}{l}\text { Congenital malformations of the musculoskeletal system, not } \\
\text { elsewhere classified }\end{array}$ & Q79.0-Q79.4 \\
\hline & Chromosomal abnormalities, not elsewhere classified & Q90-Q99 \\
\hline
\end{tabular}


Table 1. Distribution of hospitalizations by chronic clinical conditions (number, percentage with respective confidence interval of $95 \%$ and rate per 100,000 inhabitants) by region, age and chapter of the International Classification of Diseases (10 $0^{\text {th }}$ Revision; ICD-10), Brazil, 2013.

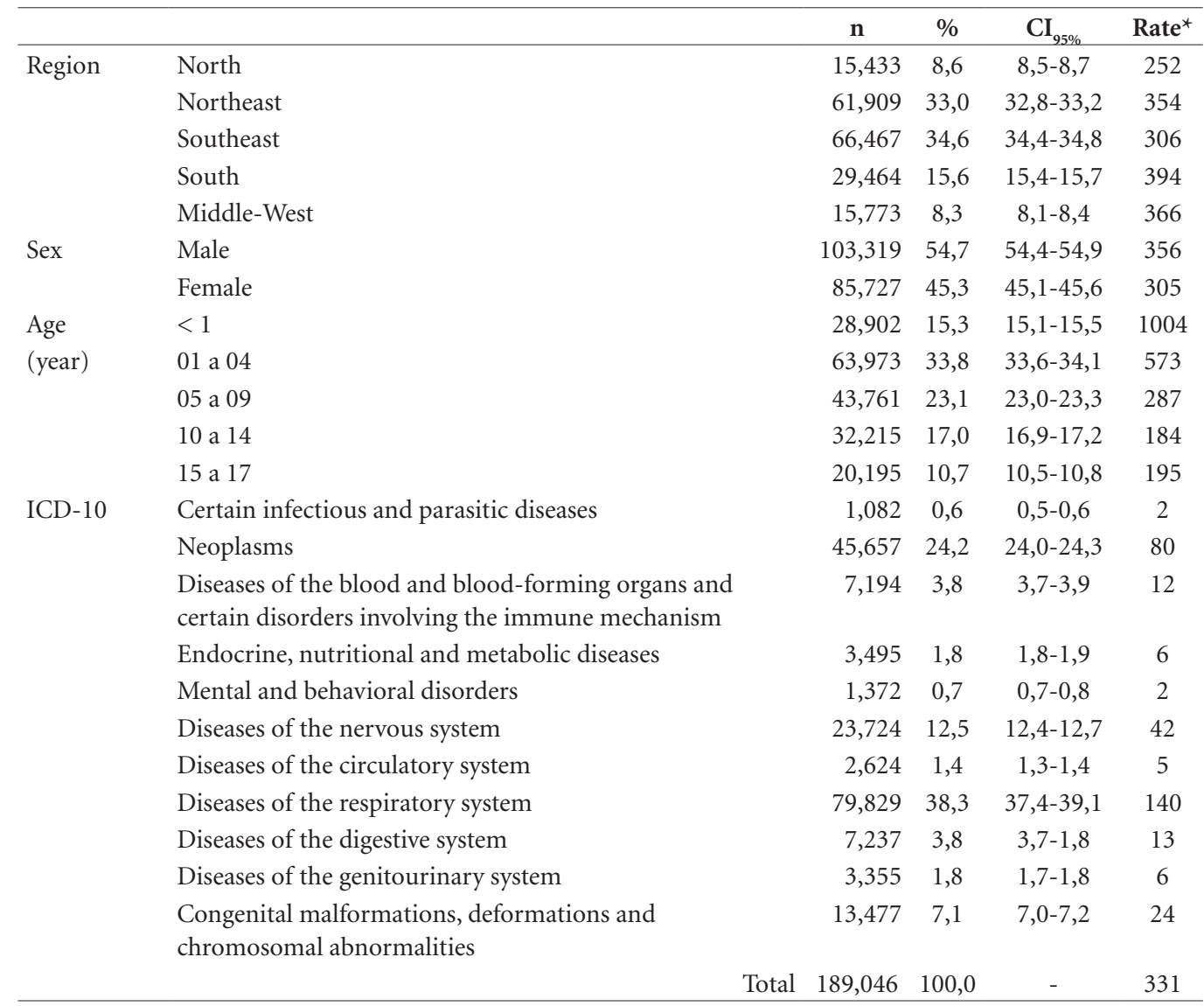

The mean duration of hospitalization was six days, ranging from zero to 353 . Only $13.5 \%$ of hospitalizations required highly complex care and the mortality rate was $1.3 \%$. The three most frequent causes of hospitalization were diseases of the respiratory system, neoplasms and diseases of the nervous system.

For all patients aged less than 18 years old, among diseases of the respiratory system, the three most common were asthma $(83.0 \%)$, bronchitis, emphysema and other chronic obstructive pulmonary disease $(16.5 \%)$ and bronchiectasis $(0.5 \%)$, according to ICD identification. Children under the age of one year had the highest rates. The Northeast Region had the highest rates and the Southeast the lowest. The mean duration of hospitalization for diseases of the respiratory system was 3.8 days, ranging from zero to 353 .

In respect to neoplasms, in all age groups the highest rates were found in the South region and among children aged between one and four years. The mean duration of hospitalization was 6.6 days, ranging from 5.5 days in the Mid-West Region to 9.9 days in the North.

Concerning diseases of the nervous system, the three most common diseases were epilepsy (79.3\%), cerebral palsy and other paralytic syndromes (20.4\%) and multiple sclerosis (0.3). The highest rate occurs in the first year of life, being higher in the South and less in the North. The duration of hospitalization for diseases of the nervous system ranged from one to 263 days, and the mean duration was 7.3.

Table 2 shows the higher percentage of male than female in all regions, as well in the group age from one to four years old. The three most common causes of hospitalization were diseases of the respiratory system, neoplasms and diseases of the nervous system. However, the percentage of hospitalization by neoplasms and diseases of 
Table 2. Distribution (percentage with respective confidence interval of 95\%) of hospitalizations by chronic clinical conditions by sex, age and chapter of the International Classification of Diseases $\left(10^{\text {th }}\right.$ Revision; ICD-10) according to region Brazil, 2013.

\begin{tabular}{|c|c|c|c|c|c|c|}
\hline & & \multicolumn{5}{|c|}{ Region } \\
\hline & & North & Northeast & Southeast & South & Middle-West \\
\hline \multirow[t]{4}{*}{ Sex } & Male & 53.7 & 54.6 & 54.9 & 55.1 & 53.8 \\
\hline & & $(52.9-54.4)$ & $(54.2-55.0)$ & $(54.5-55.3)$ & $(54.6-55.7)$ & $(53.1-54.6)$ \\
\hline & Female & 46.3 & 45.4 & 45.1 & 44.9 & 46.2 \\
\hline & & $(45.6-47.1)$ & $(45.0-45.8)$ & $(44.7-45.5)$ & $(44.3-45.4)$ & $(45.4-46.9)$ \\
\hline \multirow{10}{*}{$\begin{array}{l}\text { Age } \\
\text { (year) }\end{array}$} & $<1$ & 14.6 & 14.0 & 15.9 & 16.6 & 16.2 \\
\hline & & $(14.0-15.1)$ & $(13.7-14.2)$ & $(15.6-16.2)$ & $(16.2-17.1)$ & $(15.6-16.8)$ \\
\hline & 01 a 04 & 35.4 & 35.1 & 32.2 & 33.7 & 34.3 \\
\hline & & $(34.7-36.2)$ & $(34.7-35.5)$ & $(31.8-32.6)$ & $(33.2-34.3)$ & $(33.5-35.0)$ \\
\hline & 05 a 09 & 23.7 & 23.7 & 23.0 & 21.6 & 23.7 \\
\hline & & $(23.1-24.4)$ & $(23.4-24.1)$ & $(22.7-23.3)$ & $(21.2-22.1)$ & $(23.1-24.4)$ \\
\hline & 10 a 14 & 16.4 & 17.2 & 17.3 & 17.0 & 15.8 \\
\hline & & $(15.9-17.0)$ & (16.9-17.5) & $(17.0-17.6)$ & $(16.6-17.4)$ & $(15.2-16.4)$ \\
\hline & 15 a 17 & 9.8 & 10.0 & 11.6 & 11.0 & 10.0 \\
\hline & & $(9.4-10.3)$ & $(9.8-10.2)$ & $(11.3-11.8)$ & (10.6-11.3) & $(9.5-10.5)$ \\
\hline \multirow[t]{22}{*}{ ICD-10 } & Certain infectious and & 0.4 & 0.8 & 0.6 & 0.4 & 0.4 \\
\hline & parasitic diseases & $(0.3-0.5)$ & $(0.7-0.9)$ & $(0.5-0.6)$ & $(0.3-0.5)$ & $(0.3-0.5)$ \\
\hline & Neoplasms & 16.6 & 23.2 & 26.5 & 26.1 & 26.1 \\
\hline & & $(16.0-17.1)$ & $(22.9-23.5)$ & $(26.2-26.9)$ & $(25.6-26.7)$ & $(25.6-26.7)$ \\
\hline & Diseases of the blood and & 3.1 & 3.7 & 5.1 & 1.3 & 1.3 \\
\hline & $\begin{array}{l}\text { blood-forming organs and } \\
\text { certain disorders involving } \\
\text { the immune mechanism }\end{array}$ & $(2.9-3.4)$ & $(3.5-3.8)$ & $(5.0-5.3)$ & $(1.2-1.5)$ & $(1.2-1.5)$ \\
\hline & Endocrine, nutritional and & 2.3 & 2.0 & 1.6 & 1.4 & 1.4 \\
\hline & metabolic diseases & $(2.1-2.6)$ & $(1.9-2.1)$ & $(1.5-1.7)$ & $(1.2-1.5)$ & $(1.2-1.5)$ \\
\hline & Mental and behavioral & 0.3 & 0.3 & 1.2 & 0.8 & 0.8 \\
\hline & disorders & $(0.2-0.4)$ & $(0.3-0.4)$ & $(1.1-1.3)$ & $(0.7-0.9)$ & $(0.7-0.9)$ \\
\hline & Diseases of the nervous & 9.3 & 8.4 & 15.7 & 15.3 & 15.3 \\
\hline & system & $(8.9-9.7)$ & $(8.2-8.6)$ & $(15.5-16.0)$ & $(14.8-15.7)$ & $(14.8-15.7)$ \\
\hline & Diseases of the circulatory & 0.8 & 0.9 & 1.7 & 1.6 & 1.6 \\
\hline & system & $(0.7-0.9)$ & $(0.9-1.0)$ & $(1.6-1.8)$ & $(1.5-1.8)$ & $(1.5-1.8)$ \\
\hline & Diseases of the respiratory & 53.0 & 49.6 & 33.8 & 40.1 & 40.1 \\
\hline & system & $(52.3-53.8)$ & $(49.2-50.0)$ & $(33.4-34.1)$ & $(39.6-40.7)$ & $(39.6-40.7)$ \\
\hline & Diseases of the digestive & 6.2 & 3.4 & 3.3 & 4.3 & 4.3 \\
\hline & system & $(5.8-6.6)$ & $(3.2-3.5)$ & $(3.2-3.4)$ & $(4.0-4.5)$ & $(4.0-4.5)$ \\
\hline & Diseases of the & 2.2 & 1.5 & 1.8 & 1.9 & 1.9 \\
\hline & genitourinary system & $(1.9-2.4)$ & $(1.5-1.6)$ & $(1.7-1.9)$ & $(1.7-2.0)$ & $(1.7-2.0)$ \\
\hline & Congenital malformations, & 5.8 & 6.1 & 8.7 & 6.7 & 6.7 \\
\hline & $\begin{array}{l}\text { deformations and } \\
\text { chromosomal abnormalities }\end{array}$ & $(5.4-6.1)$ & $(5.9-6.3)$ & $(8.5-8.9)$ & $(6.5-7.0)$ & $(6.5-7.0)$ \\
\hline
\end{tabular}

the nervous system is higher in Southeast, South and Middle-West and, consequently, higher by diseases of the respiratory system in North and Northeast.

\section{Discussion}

This study reports an incidence rate of hospitalizations for children and adolescents with CCC of 331 per 100,000 inhabitants. We identified diseases of the respiratory system (asthma), neoplasms and diseases of the nervous system (epi- 
lepsy and cerebral palsy and other paralytic syndromes) as the most common basic diagnosis. These findings are consistent with those reported by Berry et al. ${ }^{15}$, who found asthma and cerebral palsy to be among the most common primary diagnoses in the United States during 2009, with epilepsy accounting for $4.1 \%$. In Brazil, it is possible that there is an over reporting of epilepsy as the basic diagnosis instead of cerebral palsy because of the presence of a convulsion, a symptom that is not just related to epilepsy and may mean erroneous diagnoses.

In developed countries, the prevalence of cerebral palsy ranges from 1.5 to 5.9 per 1,000 live births; the incidence in developing countries is estimated at 7.0 per 1,000 live births, characterizing a great rate. The magnitude of this issue led the Brazilian Ministry of Health to publish a document about healthcare for people with cerebral palsy ${ }^{16}$. The document is focused on pregnancy, children and childcare. Different development patterns among countries may explain the diversity of data between countries, principally related to poor primary prenatal and birth care. The severity of cerebral palsy is associated with limitations in physical activity and the presence of associated diseases. This portrayal could serve as a definition of CCC. Complexity does not relate to a single issue in the health system, as Mendes points out ${ }^{17}$. In this paper, complexity is considered as part of the subject, and complexity is incorporated by the child and in his or her health conditions.

Different to Simon et al. ${ }^{10}$ who, using CID-9 chapters, mainly observed cardiovascular, congenital, neuromuscular, respiratory diseases and neoplasia, in decreasing order and all above $15 \%$, we found mainly respiratory diseases $(42.2 \%)$, neoplasia $(24.2 \%)$, diseases of the nervous system $(12.5 \%)$ and congenital malformations, deformations and chromosomal abnormalities $(7.1 \%)$. Though, the difference in the proportion of causes of hospitalization among could be reflex of the health services offer, because Southeast, South and Middle-West regions are characterized as high technology centers.

The mean duration of hospitalization was six days, ranging from zero to 353 . Only $13.5 \%$ of all hospitalizations required highly complex care and the mortality rate was $1.3 \%$. This mean duration was similar to that observed by Simon et al. ${ }^{10}$, but the mortality rate was 10 times less. This may also be explained by the over reporting of epilepsy, leading to a decrease in related mortality rates because the prognosis of this disease is not death.
Newacheck and $\mathrm{Kim}^{8}$, studying the population aged less than 18 years in the United States, found a higher incidence among male than female patients, an increase with age, and accounting for $15.5 \%$ of this population in 2000 . In the study, Simon et al. ${ }^{10}$ also pointed to a higher rate among men and among children under the age of two years, which is consistent with our results if we group patients under two years (41.5\%).

It is important to point out that there is a greater rate of hospitalizations for CCC during the first year of life, which is characterized by fast growth and skills development (motor, social, communication and cognitive). This factor, along with long-term hospitalizations or repeated admissions, may compromise the well-being of the patient and of their family. It is necessary to offer adequate hospital conditions in order to meet the specific needs of CCC patients, stimulating their growth and abilities, and to think about health promotion and damage prevention.

The main limitation of this study concerns the data source. The National Health Information System does not include data from institutions that are exclusively private, which represents $21 \%$ of total hospitalizations. This makes it possible to estimate the total number of CCC hospitalizations in the country as 240,000 , which accounts for a little more than $10 \%$ of all hospitalizations among people under the age of 18 years. This estimate is close to Simon et al.'s ${ }^{10}$ findings who identify $10.1 \%$ of under 18 years Americans as having been hospitalized for CCC in 2006. In so far, population epidemiological data in this age is available only from United States, which limits the comparability with others countries.

In 2009 in the United States, data from 400,000 patients aged below 18 years showed that $65 \%$ of hospitalizations were for $\mathrm{CCC}^{15}$, representing an increase of $13.7 \%$ since 2004 .

In Brazil, this number represents less than $1 \%$ of the entire population of children and adolescents, which is all 64 million. However, the majority of hospitalizations occur due to acute episodes and not CCC. The hospital system does not make it obligatory to register secondary causes; which could allow for the identification of other CCC cases. Kuo et al. ${ }^{18}$ analyzed combined data from 2005-06 and 2009-10 of an American national survey made by telephone interviews and found a CCC estimated prevalence of $2.7 \%$. This survey also identified a higher proportion among men and among children under the age of six years. Considering that, Brazilian data includes just one diagnosis and often the hospitalization 
of CCC patients occurs because of an acute episode, the population prevalence is expected to be greater than $1 \%$.

Regarding hospitalization data in Brazil, the South region presents the highest rate and the North region the lowest. This may reflect access to specialized health services, because the most developed hospitals are found in the South, which also has the highest rate of life expectancy in the country ${ }^{19}$.

Other limitations include diagnosis mistakes, repeated hospitalizations and patient transfers that are not identified by the hospital system, as well as the selective morbidity caused by a single diagnosis. Nevertheless, it is important to use the hospital database system in order to quantify hospitalizations and to point to the fragility of the system in order to improve the registration of data including the CID's secondary and associated diagnoses.

In spite of these limitations, this study was the first in Brazil that has sought to estimate the magnitude of CCC. The use of recent data avoids helps to avoid many diagnoses mistakes because of improvements in hospital performance during this time. This makes it possible to establish a CCC baseline in Brazil, but it is not possible to identify trends because there is no estimate of the number of mistaken diagnoses over the time.

The use of rates makes it possible to compare groups, and the proportion shows the size of each group in the country. This can support decisions on resource allocation according to the respective proportion, which is greater in the Northeast and Southeast, for example. It is important do highlight the exploratory character of this study and to point out the need of more detailed hospitalization data, including secondary diagnosis of hospitalization.
Indeed, at least 240,000 children and adolescents are hospitalized each year, representing an important proportion of the overall hospital population, thereby making this an important emerging public health issue in Brazil. In this way, the situation of children and adolescents with CCC calls for a "new pediatrics" in Bra$\mathrm{zil}^{20}$ with diversified professional resources and technology, with the preparation of a specific health plan and program that is consistent with the National Health Policy and aims to provide adequate and comprehensive care to all children and adolescents with $\mathrm{CCC}^{21}$. Nonetheless, more studies are necessary in order to identify the true dimension of CCC in Brazil, besides to compare the evolution throughout the time.

\section{Collaborations}

EC Moura: substantial contributions to conception and design, acquisition, analysis and interpretation of data, drafting the article; MCN Moreira: substantial contributions to conception, interpretation of data, critical revision, drafting the article; LA Menezes: substantial contributions to conception, critical revision, interpretation of data, final approval; IA Ferreira: acquisition of data, critical revision, final approval; R Gomes: interpretation of data, critical revision, final approval. 


\section{References}

1. Organização Mundial da Saúde (OMS). Cuidados inovadores para condições crônicas: componentes estruturais de ação: relatório mundial. Brasília: OMS; 2003.

2. Cohen E, Kuo DZ, Agrawal R, Berry JG, Bhagat SKM, Simon TD, Srivastava R. Children with medical complexity: an emerging population for clinical and research initiatives. Pediatrics 2011; 127(3):529-538.

3. Burke RT, Alverson B. Impact of children with medically complex conditions. Pediatrics 2010; 126(9):789-800.

4. Castro EK, Piccinini CA. Implicações da doença orgânica crônica na infância para as relações familiares: algumas questões teóricas. Psicologia: reflexão e crítica 2002; 15(3):625-635.

5. Leite MF, Gomes IP, Leite MF, Oliveira BRG, Rosin J, Collet N. Condição crônica na infância durante a hospitalização: sofrimento do cuidador familiar. Cienc Cuid Saude 2012; 11(1):51-57.

6. Silva MAS, Collet N, Silva KL, Moura FM. Cotidiano da família no enfrentamento da condição crônica na infância. Acta Paul Enferm 2010; 23(3):359-365.

7. Vieira MA, Lima RAG. Crianças e adolescentes com doença crônica: convivendo com mudanças. Rev Latino am Enfermagem 2002; 10(4):55-60.

8. Newacheck PW, Kim SE. A national profile of health care utilization and expenditures for children with special health care needs. Arch Pediatr Adolesc Med 2005; 159(1):10-17.

9. Burns KH, Casey PH, Lyle RE, Bird, TM, Fussel JJ, Robbins JM. Increasing prevalence of medically complex children in US Hospitals. Pediatrics 2010; 126(9):638646.

10. Simon TD, Berry J, Feudtner C, Stone BL, Sheng X, Bratton SL, Dean JM, Srivastava R. Children with chronic conditions in inpatient hospital settings in the United States. Pediatrics 2010; 126(4):647-655.

11. Flores JC, Carrillo D, Karzulovic L, Cerda J, Araya G, Matus MS, Llévenes G, Menchaca G, Vargas NA. Niños y adolescentes con necesidades especiales de atención en salud: prevalencia hospitalaria y riesgos asociados. Rev Med Chile 2012; 140(s/n):458-465.
12. Bethell CD, Read D, Blumberg SJ, Newacheck P. What is the prevalence of children with special health care needs? Toward an understanding of variations in findings and methods across three national surveys. Matern Child Healt J 2008; 12(6):1-14.

13. World Health Organization (WHO). International statistical classification of diseases and related health problems (CID 10). 10 $0^{\text {th }}$ ed. Geneva: WHO; 2010.

14. Feudtner T, Hays RM, Haynes G, Geyer JR, Neff JM, Koepsell TD. Deaths attributed to pediatric complex chronic conditions: national trends and implications for supportive care services. Pediatrics 2001; 107(11):647-655.

15. Berry JG, Hall M, Hall DE, Kuo DZ, Cohen E, Agrawal $\mathrm{R}$, Mandl KD, Clifton H, Neff J. Inpatient growth and resource use in 28 children's hospital. JAMA Pediatr 2008; 167(2):170-177.

16. Brasil. Ministério da Saúde (MS). Diretrizes de atenção à pessoa com paralisia cerebral. Brasília: MS; 2013.

17. Mendes EV. As redes de atenção à saúde. Brasília: Organização Pan-Americana da Saúde; 2011.

18. Kuo DZ, Goudie A, Cohen E, Houtrow A, Agrawal R, Carle AC, Wells N. Inequities in health care needs for children with medical complexity. Health Affairs 2014; 33(12):2190-2198.

19. Brasil. Ministério da Saúde (MS). Saúde Brasil 2013: uma análise da situação de saúde e das doenças transmissíveis relacionadas à pobreza. Brasília: MS; 2014.

20. Moreira MEL, Goldani MZ. A criança é o pai do homem: novos desafios para a área de saúde da criança. Cien Saude Colet 2010; 15(2):321-327.

21. Moreira MCN, Sá MRC, Gomes R. Doenças crônicas em crianças e adolescentes: uma revisão bibliográfica. Cien Saude Colet 2014; 19(7):2083-2094.

Artigo apresentado em 11/10/2015

Aprovado em 02/03/2016

Versão final apresentada em 04/03/2016 